\title{
The Quality of Postgraduate in Law in Mexico: Case UABC
}

\author{
Yolanda Sosa y Silva García, María Salomé Magaña Martínez, Jesús Rodríguez Cebreros \\ Universidad Autónoma de Baja California (UABC), Mexicali, México \\ Manuel Jiménez López \\ Universidad Juárez del Estado de Durango (UJED), Durango, México
}

\begin{abstract}
This article aims to expose the experience of the Faculty of Law in the Doctorate in Legal Sciences Educational Program, reflecting on the strengths and areas of opportunity that contribute to raising the quality of postgraduate education in Mexico. Firstly, the problem of higher education institutions that teach a law degree is presented, after which brief background of both the National Autonomous University of Mexico (UNAM) and the UABC are reported in order to locate the doctorate program in legal sciences.
\end{abstract}

Keywords: educational quality, strengths, areas of opportunity

\section{Introduction}

Mexico according to the information of 2015 that corresponds to an estimate of the total population made based on the Intercensal Survey (EIC) that allows its comparison with the census series had a population of 119 million 938,473 inhabitants ${ }^{1}$ and according to the 2015 report of the CEEAD ${ }^{2}$ for the 2013-2014 school year, 1,608 higher education institutions offered the degree in law, which means that for every 74,589 inhabitants there is a higher education institution offering legal studies.

The report mentions that these institutions are home to 255 thousand students, also states that $98.5 \%$ of these institutions are private, that is, only $1.5 \%$ are public universities, for all the above, it is necessary to highlight the quality of education of law, specifically in their postgraduate studies.

\section{National Autonomous University of Mexico (UNAM)}

At the time of the conquest of Mexico, the colonizers realized that it was necessary to establish schools in New Spain, so that there would be people with knowledge in theology and law to help the missionaries in their colonization work and provide a service to the Spanish crown.

Yolanda Sosa y Silva García, Doctor in law, professor, Law School, Universidad Autónoma de Baja California (UABC), Mexicali, México.

María Salomé Magaña Martínez, Doctor in law, profesor, Law School, Universidad Autónoma de Baja California (UABC), Mexicali, México.

Jesús Rodríguez Cebreros, Doctor in law, professor, Law School, Universidad Autónoma de Baja California (UABC), Mexicali, México.

Manuel Jiménez López, Doctor in law, profesor, Law School, Universidad Juárez del Estado de Durango (UJED), Durango, México.

${ }^{1}$ Instituto Nacional de Estadística y Geografía http://www.beta.inegi.org.mx/temas/estructura/ recuperado 13 de agosto de 2018.

2 Centro de Estudios sobre la Enseñanza y el Aprendizaje del Derecho http://www.ceead.org.mx/ recuperado 13 de agosto de 2018. 
The great promoters of these education centers of the New Spain were, among others, Fray Pedro de Gante, Fray Bartolomé de las Casas, and the Viceroy Don Antonio de Mendoza; the latter made arrangements with the king to found a university.

Thus, on September 21, 1551, the foundation of the University of Mexico was ordered by a royal decree dictated by King Felipe II in the city of Toro. At 12:00 hours on July 12, 1553, the first lecture of Law School was issued, being philosophy, although the first curriculum of the law course was developed on 1526 (Sosa y Silva García, 2009). From October 7, 1595, it became known as "The Royal and Pontifical University of Mexico", by a decree granted by Pope Clement VIII at Frascati, Italy.

Probably, the University, as far as law is concerned, always maintained a scientific stature; it was wanted that in it guiding principles of that discipline were taught, at side lines from any change in the legislation; for that reason, to exercise the profession as a lawyer it was necessary to sustain examination before the Real Hearing, act in which the interested party had to demonstrate his knowledge on the positive current law and about judicial practices. That is, it was not enough to litigate in court rooms, the title of doctor or law degree issued by the University, because that title had a purely academic value. (Mendieta y Nuñez, 1956, p. 92)

It is preceded by the National University Major of San Marcos of Peru, which is recognized as the oldest university in America, created by royal decree and by mandate of the Spanish crown, Real Provisión, on May 12, 1551. Recognition deserved not only for the date of its foundation but for being the only university from those created in the sixteenth century that has offered its educational services in an uninterrupted manner. This is so, because many of the universities were created in the American continent were closed during the Spanish-American independence wars or afterwards because of conflicts that emerged within the universities themselves. The UNAM does not escape from this premise.

Time passed and many hardships with it, until July 9, 1929, the UNAM was created. By law, it was a public autonomous corporation, granted with full legal capacity; however, the appointment of a dean rector attributed the federal executive power.

In 1980, Article 3 of the Political Constitution of the United Mexican States was reformed, raising the autonomy of the university to a constitutional rank.

\section{Autonomous University of the State of Baja California (UABC)}

The 1957 was decisive year for the development of Baja California, Mexico, when the first public university in the state was created: the Autonomous University of the State of Baja California.

October 27, 1973 officially marks the birth of the Law School, with the approval of the University Council, in ordinary session, held in the city of Tijuana, Baja California. It has distinguished itself as an institution of higher education of great tradition, maker of graduates and postgraduates in law, prepared with the highest academic levels of the nation and with a broad sense of ethical and social responsibility. From 1973 to 1979, the foundations were laid for the operation of the school, establishing an organizational program with an interim curriculum, borrowed from UNAM (Sosa y Silva García, 2009, pp. 57-62).

\section{National Quality Postgraduate Program (PNPC)}

For many years, in Mexico, the aim is to promote quality in the graduate programs. Thus, 
Since 1991, the $\mathrm{SEP}^{3}$ and CONACYT ${ }^{4}$ have been promoting the public policy of the promoting postgraduate quality through the programs offered in higher education institutions and research centers, through rigorous peer evaluation processes, those programs which prove to comply with the highest standards of quality and pertinence. (Moctezuma Hernández et al., 2015, p. 41)

In this regard, the National Development Plan 2013-2018 within its strategy 3.5.2, "To contribute to the formation and strengthening of high-level human capital” establishes the commitment to promote the quality of education provided in graduate programs, through its accreditation in the National Postgraduate Quality Program (PNPC), which affects the positive transformation of society and knowledge (Gobierno Constitucional de los Estados Unidos Mexicanos, 2013). As a result, currently sixteen doctoral programs are offered in Mexico in the area of social sciences, specifically legal sciences or law, registered in the PNPC, according to the information provided in Table 1 under the title of doctorates in the area of law with PNPC registration, which specifies the name of the doctoral program, registration number to the PNPC, the university that provides it and the federative entity of its location.

Table 1

Doctorates in the Area of Law With PNPC Registration

\begin{tabular}{llll}
\hline Programa de doctorado & PNPC & Universidad que imparte & Entidad Federativa \\
\hline Doctorado en Ciencias del Derecho & 002826 & Universidad Autónoma de Sinaloa & Sinaloa \\
Doctorado en Ciencias Jurídicas & 5252 & Universidad Autónoma de Querétaro & Querétaro \\
Doctorado en Ciencias Jurídicas & 004302 & Universidad Autónoma de Baja California & Baja California \\
Doctorado en Derecho & 001324 & Benemérita Universidad Autónoma de Puebla & Puebla \\
Doctorado en Derecho & 000409 & Universidad Autónoma de Nuevo León & Nuevo León \\
Doctorado en Derecho & 004122 & Universidad Autónoma de Chiapas & Chiapas \\
Doctorado en Derecho & 000257 & Universidad Nacional Autónoma de México & Ciudad de México \\
Doctorado en Derecho y Globalización & 002764 & Universidad Autónoma del Estado de Morelos & Morelos \\
$\begin{array}{l}\text { Doctorado en Estudios Jurídicos } \\
\text { Doctorado en Métodos Alternos de }\end{array}$ & 003923 & Universidad Juárez Autónoma de Tabasco & Tabasco \\
Solución de Conflictos & 003396 & Universidad Autónoma de Nuevo León & Nuevo León \\
$\begin{array}{l}\text { Doctorado en Métodos de Solución de } \\
\text { Conflictos y Derechos Humanos }\end{array}$ & 003925 & Universidad Juárez Autónoma de Tabasco & Tabasco \\
$\begin{array}{l}\text { Doctorado Institucional en Derecho } \\
\text { Doctorado Interinstitucional en Derecho }\end{array}$ & 003468 & Universidad Juárez del Estado de Durango & Durango \\
$\begin{array}{l}\text { Doctorado en Criminología } \\
\text { Doctorado en Derecho y Argumentación }\end{array}$ & 003397 & Universidad Autónoma de Nayarit & Nayarit \\
Jurídica & 005344 & Universidad Autónoma de Nuevo León & Nuevo León \\
Doctorado en Derecho & 005611 & Universidad Veracruzana & Tlaxcala \\
\hline
\end{tabular}

Note. http://www.conacyt.gob.mx (recuperado 09 de enero de 2018). ${ }^{5}$

\section{Doctorate in Legal Sciences}

In an ordinary session held in the city of Tecate, Baja California, on February 25, 2014, the University Council of the UABC approved the plans and study programs of a doctorate in legal sciences curriculum and in accordance with Article 154, section II of the School Statute, to ensure the quality, relevance and equivalence of any graduate program offered at the UABC, it must be included in the records or registers of good quality

\footnotetext{
3 Secretaría de Educación Pública.

${ }^{4}$ Consejo Nacional de Ciencia y Tecnología.

${ }^{5}$ Consejo Nacional de Ciencia y Tecnología, http://www.conacyt.gob.mx, recuperado 09 de enero de 2018.
} 
programs of an integrating, evaluating or accrediting body with national or international recognition and that in this case which concerns us is the PNPC of Consejo Nacional de Ciencia y Tecnología (CONACYT), counting this educational program with newly created rating and registration number 004302.

The doctorate in legal sciences is constituted as an innovative proposal, unique at its level in the northwest region of the country emanating from a public institution, such as the UABC which seeks to train human resources and develop legal research at the highest level.

The general objective of this educational program is the formation of human resources in the area of legal sciences, capable of generating knowledge and carrying out collegiate and independent research, participate in teaching activities and act as high-level professionals, involved in responding to legal problems, issues that the legislation raises at the state, national, and international levels.

On February 2015, the activities of the referred program began, which is distinguished particularly by the Línea de Generación y Aplicación del Conocimiento (LGAC), social law which is not offered in the northwest region of the country and constitutional law which deals with the evolution of law at a national, state, and municipal issues.

The doctorate program in legal sciences is a flexible program, since the optional subjects may vary according to the LGAC and is aimed at full-time students. The enrolled students dedicate themselves to the academic activities established in the program and concentrate on research as a main activity, in six semesters the necessary subjects are studied to consolidate their theoretical and methodological training, including as a cluster of compulsory learning units six thesis seminars during the six semesters.

One of the factors which measure the quality of the graduate programs is compliance with the standards established by CONACYT to obtain registration in the PNPC. When the program is of recent creation, it entails a number of indicators that translate into requirements for both the students and the institutions which offers these programs. The daily tasks fulfilled each day prevent us in many cases from detecting the strengths as well as the areas of opportunity for continuous improvement. Therefore, having some proposals for that purpose, translates into time saved and optimization of human resources, so the question we ask ourselves is: do we detect in right timing our strengths and areas of opportunity, which will allow us to better the education process, which will translate in a much better quality of education?

On this occasion, we will describe only one strong point and one area of opportunity of the three phases in which the educational process could be divided for purposes of this article, solely:

The first phase consists of the selection process, during which the interviews are carried out with the aspirants to enter the program by the members of the Studies Committee, this being a key phase given that the applicant exposes motive for wanting to be included in the program, which in a general context is analyzed, the curricular evaluation, the review of the research protocol and the results of the knowledge and language exams respectively are included. This analysis yields a comprehensive evaluation of the applicants profile and provides the necessary inputs to the interviewers for them to be able to issue an objective numerical note that will determine their entry to the program. The required documentation for entrance to the program by itself does not contribute a comprehensive evaluation, and it is through the interview that the knowledge, skills, values, and attitudes necessary to attend the educational program are detected and/or confirmed, with emphasis on the need to focus on research lines and topics to be investigated during their stay in the program.

Regarding the areas of opportunities in this phase, we have the knowledge exam that was applied to the aspirants of the 2015-2017 generation itself, which was designed, elaborated, applied, and evaluated by the 
Program Coordinator, with the support of the Studies Committee and the members of the academic bodies related to LGAC, social law and constitutional law. Nonetheless, a standardized evaluation document must be used, in which external academic peers that endorse the knowledge and skills of the applicants participate.

In the second phase in relation to the evolvement of the program, we have one of the specific objectives of the program, is to promote student mobility through short research stay programs. To achieve this goal, we tried to comply with some aspects, such as the institution of destination preferably has a doctorate registered in the PNPC, or that it be well known in the legal field; that the LGAC of the host researcher be consistent with the work developed by the students; that the job to be done during such stay under the host researcher would have an impact on some thematic axis proposed by the student. In addition, it was estimated that the duration of the short stay of investigation should not be less than thirty days. As a consequence of the above, three students completed their stay abroad and six in the country, beginning the summer 2016 and ending up to the spring of 2017.

With respect the area of opportunity, it is a complex situation which represents the requirement related to the publication of an article by the student in conjunction with his tutor/thesis supervisor in refereed or indexed journals, since different actors intervene, the process is diluted and leads to downtime. A first character could be the researcher who in most cases faces his first time experience of this nature, as a characteristic note the insecurity of a beginner in these academic tasks, delays the time of conclusion of the article, notwithstanding the before mentioned conjunction. A second actor could be represented by the complexity of receiving, reviewing, approving, and publishing the referred article, since each journal establishes its own requirements and editorial processes, which always represent waiting time. The above should call for a deep reflection of when is the best time to start complying with this requirement? Although it is true that it can be done from the beginning of the program, the ideas may not be as mature as if they were present once in a later stage, having as a counterpoint that it would not be published in the required times.

Within the third phase or conclusion, the greatest challenge presented by any educational program is the terminal efficiency, as corroborated by the CONACYT indicator, giving only six months after the conclusion of the school phase, to obtain the degree. One of the successes in the execution of the program was that all the study units had an impact on the ending jobs and thus contribute to the creation of the document that would ultimately become the thesis. Thus, at the end of the sixth semester the students obtained as a product not only the document in its final version but also the approval votes of the members of their thesis committees, so that in the next six months, the administrative procedures necessary to hold the degree exams would take place.

Undoubtedly, the area of opportunity that provides a better design is definitely, having to accredit a third language as a graduation requirement. Although it is true that the reference document does not specify the level according to the "Common European Framework of Reference for languages learning, teaching, and evaluation”, it indicates the levels, namely, A1 and A2, basic user; B1 and B2, independent user; C1 and C2, competent user. Therefore, it should be understood that the level needed for the understanding of legal texts is located at the C1 level where the specific competences are: being able to understand a great variety of extensive texts and with a certain level of demand, as well as recognizing implicit meanings in them; knowing how to express oneself fluently and spontaneously without loss of words or effort to find the right expression; a flexible and effective use of the language for social, academic, and professional purposes; must be able to produce well-structured, clear,

\footnotetext{
6 Marco común europeo de referencia para las lenguas: aprendizaje, enseñanza y evaluación, https://cvc.cervantes.es/ensenanza/biblioteca_ele/marco/cvc_mer.pdf, recuperado 05 de enero de 2018.
} 
and detailed texts on any subject with a certain complexity, showing a correct use of the mechanisms of organization, articulation, and cohesion to the text. Achieving the competence described above would be equivalent to crediting five to six courses of the selected language, which means that the student must begin immediately the educational language program and courses in order to concluded these studies, take an exam and, obtain the corresponding accreditation in the last semester of the program and thus fulfill this graduation requirement on time to able to process the respective paperwork immediately after concluding the schooling stage.

In summary, "the UABC takes on the national commitments facing higher education and recognizes in postgraduate studies the most important alternative for the country to form the high-level human recourse that it requires for its development” (Moctezuma Hernández et al., 2015, p. 62). Thus, the postgraduate educational program doctorate in legal sciences PNPC 004302 meets the standards of quality and human growth that the scientific community requires.

\section{Conclusions}

For it is true that the process of publishing in a refereed and/or indexed journal is complex, this can be taken as a benchmark for quality, by involving external bodies that evaluate some of the students' products.

The timing referred to by the CONACYT to obtain the degree, are so very possible if enough strategies are designed from the beginning of the program, one of them being that all the learning units must have an impact on the development of the final product, as it cone in the doctoral thesis.

The collegial responsibility of all the actors participating in the study program is one of the factors that sustain the assurance of quality and the continuous improvement of the program.

\section{References}

Cárabes Pedroza, J. J. et al. (1999). Fundamentos político-jurídicos de la educación en México. México: Editorial Progreso, S.A.

Consejo Nacional de Ciencia y Tecnología. México: Gobierno de la República. http://svrtmp.main.conacyt.mx/ConsultasPNPC/listar_padron.php recuperado 09 de enero de 2018.

Gobierno Constitucional de los Estados Unidos Mexicano. (2013). Plan Nacional de Desarrollo 2013-2018 (Tomo DCCXVI, No.

13). México, D.F.: Diario Oficial de la Federación.

Mendieta y Núñez, L. (1956). Historia de la facultad de derecho. México: UNAM.

Moctezuma Hernández, P., et al. (2015). 100\% de posgrados de calidad en la UABC: Políticas, logros y retos para la competitividad institucional. México: Universidad Autónoma de Baja California.

Sosa y Silva García, Y. (2009). Diagnóstico de necesidades de posgrado en derecho. México: Universidad Autónoma de Baja California.

Sosa y Silva García, Y., et al. (2013). La enseñanza del derecho ante el nuevo sistema de justicia penal adversarial. México: Universidad Autónoma de Baja California. 